\title{
The Game as a Strategy of Learning Chemistry Among High School Students
}

\author{
Juan-Francisco Álvarez-Herrero ${ }^{1 *}$, Cristina Valls-Bautista ${ }^{2}$ \\ ${ }^{1}$ Departamento de Didáctica General y Didácticas Específicas, Universidad de Alicante, Alicante, SPAIN \\ ${ }^{2}$ Departament de Bioquímica i Biotecnologia, Universitat Rovira i Virgili, Tarragona, SPAIN \\ * Corresponding author: juanfran.alvarez@ua.es
}

Received: 3 Feb. $2021 \bullet$ Accepted: 13 Apr. 2021

Citation: Álvarez-Herrero, J.-F., \& Valls-Bautista, C. (2021). The Game as a Strategy of Learning Chemistry Among High School Students. European Journal of Science and Mathematics Education, 9(3), 80-91. https://doi.org/10.30935/scimath/10947

\begin{abstract}
:
This study consists of a longitudinal research using an active methodology to teach the contents of the periodic table to high school students, based on project-based learning and WebQuest. The aim of this investigation is to study the relationship between learning the periodic table and the type of strategy that students choose to achieve the learning outcomes related to it. Throughout the learning process of the periodic table's chemical elements we could see that, after giving total freedom to 260 students (during 5 years of investigation) in the construction of instructional materials which helped them learn the periodic table, 195 of them chose to develop a game as a tool. There was no significant difference between genders, showing that students prefer to learn in a playful, motivating and exciting way since they felt a greater interest and had a better evaluation of what they had learned about, reaching a deeper and lasting understanding, hence, a significant learning. Gamification and learning-based games are acquiring a relevant role in education centers and teachers who apply these methodologies in pedagogical approaches have increased.

Keywords: high school, introductory chemistry, chemical education research, hands-on-learning, periodic table
\end{abstract}

\section{INTRODUCTION}

Scientists run their investigations in order to solve problems which has turned technology into an important backbone to our modern society, improving our life quality (Alberts, 2009; Prieto et al., 2012; Vesterinen et al., 2016). Thus, new professions have emerged involving science and technology and, in this sense, scientists are more valuable for the society (Gauchat \& Andrews, 2018; Longino, 1990).

However, despite the relevance of science in the current society, which should be a reason to be willing to work in the science world, we have a clear lack of scientific vocations. Instead of choosing scientific fields, students nowadays opt for other subjects (Osborne \& Dillon, 2008; Tai et al., 2006; Valenti et al., 2016). A considerable decrease of the university students who choose scientific degrees has been observed. Indeed, this lack of interest is already noticeable in the secondary school (Gibson \& Chase, 2002). The areas that presented less success and interest among teenagers are chemistry and physics (Oon \& Subramaniam, 2011).

For this reason, education should reconsider the methods used to teach and learn science, especially in the secondary school. Some authors assume that if students enjoy while they are learning science and experiment positive emotions, they will value their learning process (Ainley \& Ainley, 2011a, 2011b; Álvarez-Herrero, 2019; Méndez, 2015; Zapata, 2016). 
The organization of the periodic table of the chemical elements in the 1860s was one of the greatest scientific breakthroughs; indeed, during the 20th century the periodic table became a universally recognized scientific icon. The periodic table is a classificatory scheme of the elements and summarizes the field of chemistry. Therefore, the periodic table is the basic tool used by chemistry teachers in the secondary school in order to teach the position of the elements in the periodic table and explain its properties (Martí-Centelles \& Rubio-Magnieto, 2014). This way, the learning outcomes for the secondary school students are to know the position and the symbol of the most representative elements in the periodic table, and the ability to identify the period and the group of each element.

Learning the periodic table elements is a key tool to face the chemistry learning outcomes in the 3rd course of the secondary school according to the educative Spanish system. However, it is usually taught through a passive methodology: the teacher is a mere transmitter of the contents and the student body is not appealed to get involved in the process. As a consequence, its study raises negative attitudes towards chemistry (Franco-Mariscal \& Oliva-Martínez, 2012; Ogembo et al., 2015; Salta \& Tzougraki, 2004).

One of the main drawbacks for chemistry students is to learn by heart the periodic table, as they find it too challenging. Therefore, the use of creative and active educational approaches such as Project-Based Learning (PBL), Game-Based Learning (GBL), or flipped classroom) to engage students in participatory and entertaining methods might solve this problem. Games are a teaching alternative as they can be designed to teach these specific topics that could be perceived as uninteresting for the students, and this might allow students to learn in more enjoyable way compared to the traditional lecture format (Kangas et al., 2017; Rastegarpour \& Marashi, 2012).

In this regard, active methodologies are those characterized by the student as the center of the learning process making themselves the main character when gaining knowledge. Therefore, teachers' roles change; they turn into a guide that leads the students while they learn the subject. There is evidence which shows that if students learn by means of an active methodology their academic results improve (Freeman et al., 2014; Olakanmi, 2017), irrespective of the type of students, the teachers' characteristics and even regardless of the number of the students in class. Moreover, the use of active methodologies makes students increase their positive beliefs towards science (Tarhan \& Acar-Sesen, 2013). In addition, some researchers notice slight improvement in less crowded classes (Wilson \& Varna-Nelson, 2016).

Some of the most popular and reliable active methodologies are: PBL, the flipped classroom method, GBL and the WebQuest which are having a big impact in the secondary school education. The application of some of these methodologies in the learning-teaching process has shown lots of advantages in comparison to the traditional ones (González-Gómez et al., 2016; Orlik, 2002). The use of information and communication technology (ICT) should not overlook the fact that they could increase the value and quality of the learning outcome, provided that there is a correct use when they are performed in combination with active methodologies (Abdullahi, 2014; Sutherland et al., 2004; Webb, 2005).

Since the development of the WebQuest (Dodge, 1998), it has become popular in many educational areas and has received considerable attention from teachers. The WebQuest is a computer-based teaching and a learning approach in which students are actively involved in an activity which requires the use of Web-based resources. Dodge defined two types of WebQuests: short-term and long-term. Short-term WebQuest engages learners to a task which takes between one and three days to be completed. The goal is that learners acquire new information and make sense of it. Whereas the longterm WebQuest requires additional time, more than three days, and its aim is that students transform the knowledge acquired in a deep understanding and demonstrating this achievement by creating a final product. All in all, WebQuests are designed to use learners' time well, to focus on using information rather than looking for it, and to support learners' thinking on different levels, such as analysis, synthesis and evaluation (Álvarez-Herrero, 2019). 
In the literature we can find many examples regarding the use of these four methodologies when learning chemistry (Ibáñez-González \& Mazzuca-Sobczuk, 2018) and more concretely in the learning of the periodic table among secondary school students, all of which with satisfactory results. The use of integrated stories in the context of the periodic table learning (Demircioğlu et al., 2009) confirms that students are more motivated and achieve a more significant learning than when using traditional methodologies. Nevertheless, it is the use of the educative games that changes the learning process into a pleasant process and makes the students participate more in class activities. Moreover, the students' perception towards the periodic table learning process as well as the stimulation of this student body to take part in the class' activities are also enhanced, thus, they are more prone to learn (Franco-Mariscal et al., 2015). However, it is not only a matter of perception, the use of games to learn the periodic table generates a more significative learning (Joag, 2014) than the traditional methods, which should neither be neglected because some of them provide good results.

Certainly, learning is not only a cognitive process, but it also is an affective process. In this sense, the motivation of students will determine the success of learning. It is well known that there are two kinds of motivation: the intrinsic and the extrinsic. On the one hand, intrinsic motivation is the one that related to the love of learning, interest in mastering a subject or a reward that comes at the end. On the other hand, extrinsic motivation is external to us, for example: grades, parental pressures, the job or the graduate school that we will get when we are done with the program.

In the case of intrinsic motivation it tends to be more powerful but a little less under our ability to influence as instructors; whereas extrinsic motivation tends to be a little less powerful, but again we can actually generally control those fairly well. The kind of motivation that promotes a deep learning is the intrinsic one, which teachers would have to promote. There are four different points that enhance the intrinsic motivation: (i) the competence, the teacher must choose tasks that could be a challenge suitable to the students' previous knowledge, (ii) the autonomy, when students have certain decision-making capacity in their process of learning they are more motivated in the development of this task, (iii) purpose, when students know the aim of the task, they give meaning to learning, thus, their intrinsic motivation increases, (iv) social motivation, which shows that people are strongly motivated when being part of a community and by contributing to it (Ryan \& Deci, 2000).

Since the periodic table is considered a challenging and uninteresting topic by students, the aim of this work is to study the relationship between learning the periodic table and the type of strategy that students choose to achieve the learning outcomes related to it. If students learnt in the way they choose, in other words, if they have autonomy in the way that they gain knowledge, they could be more motivated and engaged in the tasks (Ryan \& Deci, 2000). And, as a result, it could improve the learning of the basic outcomes in chemistry such as to identify the chemical elements, to match the nouns of the elements with their symbols and to learn about a basic topic such as the periodic table.

\section{METHODOLOGY}

To develop this pedagogical approach, based on Project-based learning, a WebQuest was created (http://bit.ly/wqtaula) in which each part of the project is explained (Álvarez-Herrero, 2019). During the development of the project students worked in an individual and self-sufficient way. The WebQuest conducted the students by different activities which helped them reach the final goal.

The WebQuest provided the students with a menu through which they could have access to all the instructions needed:

- A presentation of the project with a brief introduction about the periodic table;

- several examples from other projects that were developed for students in previous years;

- an explanation about the task that they need to develop; 


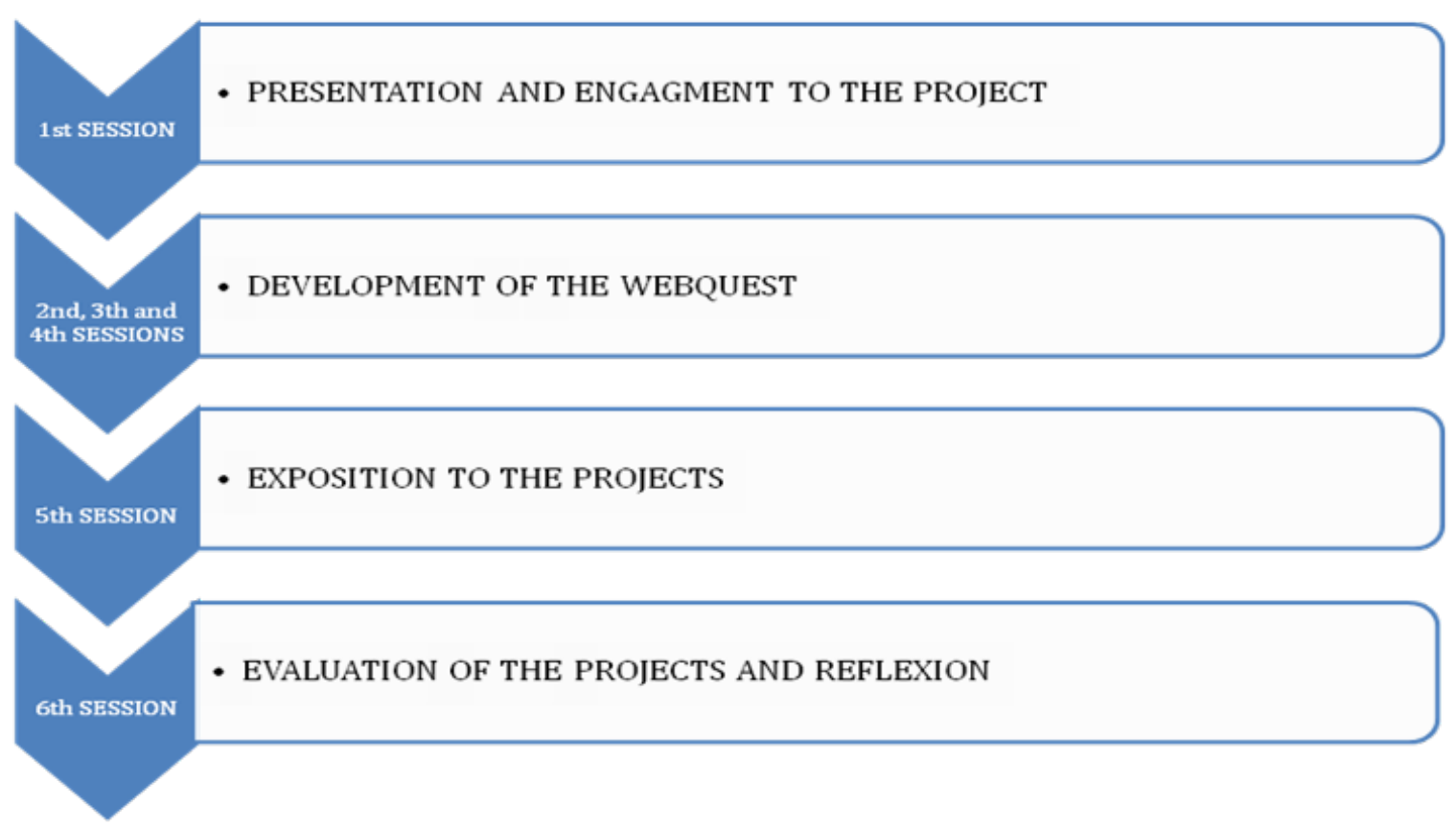

Figure 1. Workflow of the PBL methodology carried out in this investigation

- three different activities that help students in terms to know what knowledge content they need to learn each activity is accompanied with some informative videos;

- some information about the $360^{\circ}$ feedback, through which students could check the rubrics that the teacher and the other students would use to evaluate their project.

This final product had the purpose to work on, learn and evaluate the periodic table. The goal was to make the student body do a periodic table using their strongest abilities. To apply a project-based learning permit to engage students in a challenge and they realize that they must be learn some knowledge content in order to develop their project. The use of the WebQuest us a tool which conduct the project is useful because students have a guide and each of them could work on as their own pace. In this sense, students could decide on which videos or activities they needed to spend more time to internalize the knowledge.

The Project was carried out throughout six sessions (see Figure 1); the first one was the presentation of the Project in which the challenge was explained. The teachers used a video to show the projects developed by the students the year before. This session is useful because students get a few tips for their projects. Afterwards, during the three following sessions students worked in the class on their Project to ensure that students followed the WebQuest and understood the contents that they needed to develop into their projects. The fifth session consisted on an exposition of the resulting projects to the rest of the class. The students know that during the expositions the teachers take photos and videos to show their projects to the following year's students. The sixth and final session were focused on the evaluation of the projects, which was issued through a rubric, applying a $360^{\circ}$ feedback.

\section{Instruments}

In order to evaluate the projects, a rubric was used, which, in fact, the students were told about from the beginning of the task. The project applied the feedback $360^{\circ}$ to evaluate the students' creations. When the feedback $360^{\circ}$ is used the evaluation takes places from three different points of view. The first one is done by the teacher and it is called hetero-evaluation, the second one is the co-evaluation which is done by other students and, finally, the auto-evaluation in which the students check their work by 
Table 1. Students distributed by school year, gender and type of final product of the project

\begin{tabular}{lccccccccc}
\hline \multirow{2}{*}{ School year } & \multicolumn{3}{c}{ Women } & \multicolumn{3}{c}{ Men } & \multicolumn{3}{c}{ Total } \\
\cline { 2 - 10 } & $\mathrm{NG}^{\mathrm{a}}$ & $\mathrm{G}^{\mathrm{b}}$ & $\% \mathrm{G}^{\mathrm{c}}$ & $\mathrm{NG}^{\mathrm{a}}$ & $\mathrm{G}^{\mathrm{b}}$ & $\% \mathrm{G}^{\mathrm{c}}$ & $\mathrm{NG}^{\mathrm{a}}$ & $\mathrm{G}^{\mathrm{b}}$ & $\% \mathrm{G}^{\mathrm{c}}$ \\
\hline $13-14$ & 9 & 22 & 70.9 & 7 & 20 & 74.1 & 16 & 42 & 72.4 \\
$14-15$ & 7 & 24 & 77.4 & 4 & 14 & 77.7 & 11 & 38 & 77.5 \\
$15-16$ & 7 & 19 & 73.1 & 4 & 15 & 78.9 & 11 & 34 & 75.5 \\
$16-17$ & 8 & 24 & 75.0 & 3 & 16 & 84.2 & 11 & 40 & 78.4 \\
$17-18$ & 11 & 29 & 72.5 & 5 & 12 & 70.6 & 16 & 41 & 71.9 \\
\hline TOTAL & 42 & 118 & 73.7 & 23 & 77 & 77.0 & 65 & 195 & 75.0 \\
\hline
\end{tabular}

${ }^{a}$ The final project is not a game. ${ }^{\mathrm{b}}$ The final product is a game. ${ }^{\mathrm{c}}$ Percentage of projects that are games.

themselves. The results of these three independent corrections are triangulated in order to obtain an objective qualification and to guarantee the reliability of the results (Beehr et al., 2001; Wilkerson et al., 2000).

\section{Participants}

This experience was conducted over five years, with the same premise and constraints. It was carried out by 260 students of the 3rd grade of secondary compulsory education in a high school of Alcoi (Spain). These are students between the ages of 14 and 16. The students were not conditioned to develop one type of tool or another and the same motivating video was used in the introductory activity during the first session. The investigation was focused on studying the methodology that students preferred to learn the periodic table. Therefore, a PBL was set out and students had to create a project that allowed them to achieve the learning outcome previously mentioned.

\section{RESULTS}

In order to interpret the results of the final projects, they were classified into games (any game based on the periodic table or on the chemical elements were the main characters of the game) or other techniques (which involved all the projects that did not present any typical element of the game), for example: demonstratives projects, artistic projects, handicrafts, stories or tales, among others.

The results of these five years are shown in Table 1 in which the years, gender and type of project developed are detailed.

The results collected in Table 1 show that more than $70 \%$ of the students chose the game to develop their final project, regardless of the school year and the gender. But we can observe that the percentage of women (73.7\%) that chose the game was slightly lower than the percentage of men (77.0\%). It is also shown that in most of the grades there is a major number of women than of men, which can be explained since in the past, this was a typically female center and, in the same area, there is another school which was formerly exclusively for men.

Likewise, the data collected through the longitudinal field diary showed that $89 \%$ of the students, who presented a game as a periodic table project, obtained better grades than those students who presented other types of projects. This was so, since these students knew how to adjust better with their games to the requirements that the evaluation rubrics demanded from a beginning.

The evaluation of the project was carried out through a continuous evaluation in which the activities carried out during the process were rated (and which can be seen in the project webquest), as well as the ratings of the final project obtained from the hetero-evaluation, the co-evaluation and the selfevaluation through evaluation rubrics (which can also be consulted on the webquest) and which contemplate various evaluation criteria: interest, project completion, project quality, originality and creativity, curricular content, work in the classroom, etc.

Likewise, the students previously carried out the following block of chemistry contents (formulation and nomenclature of inorganic chemistry compounds) a written test to detect their knowledge about 
Table 2. Average grades and students passed in the periodic table knowledge test

\begin{tabular}{lcccc}
\hline School year & Total students & Average rating out of 10 & \multicolumn{2}{c}{ Approved students } \\
\hline $15-16$ & 45 & 8.3 & $\mathrm{n}$ & 86.7 \\
$16-17$ & 51 & 7.9 & 39 & 90.2 \\
$17-18$ & 57 & 8.1 & 46 & 91.2 \\
\hline $18-19$ & 53 & 6.2 & 52 & 58.5 \\
$19-20$ & 56 & 5.4 & 31 & 48.2 \\
$20-21$ & 54 & 4.8 & 27 & 44.4 \\
\hline
\end{tabular}
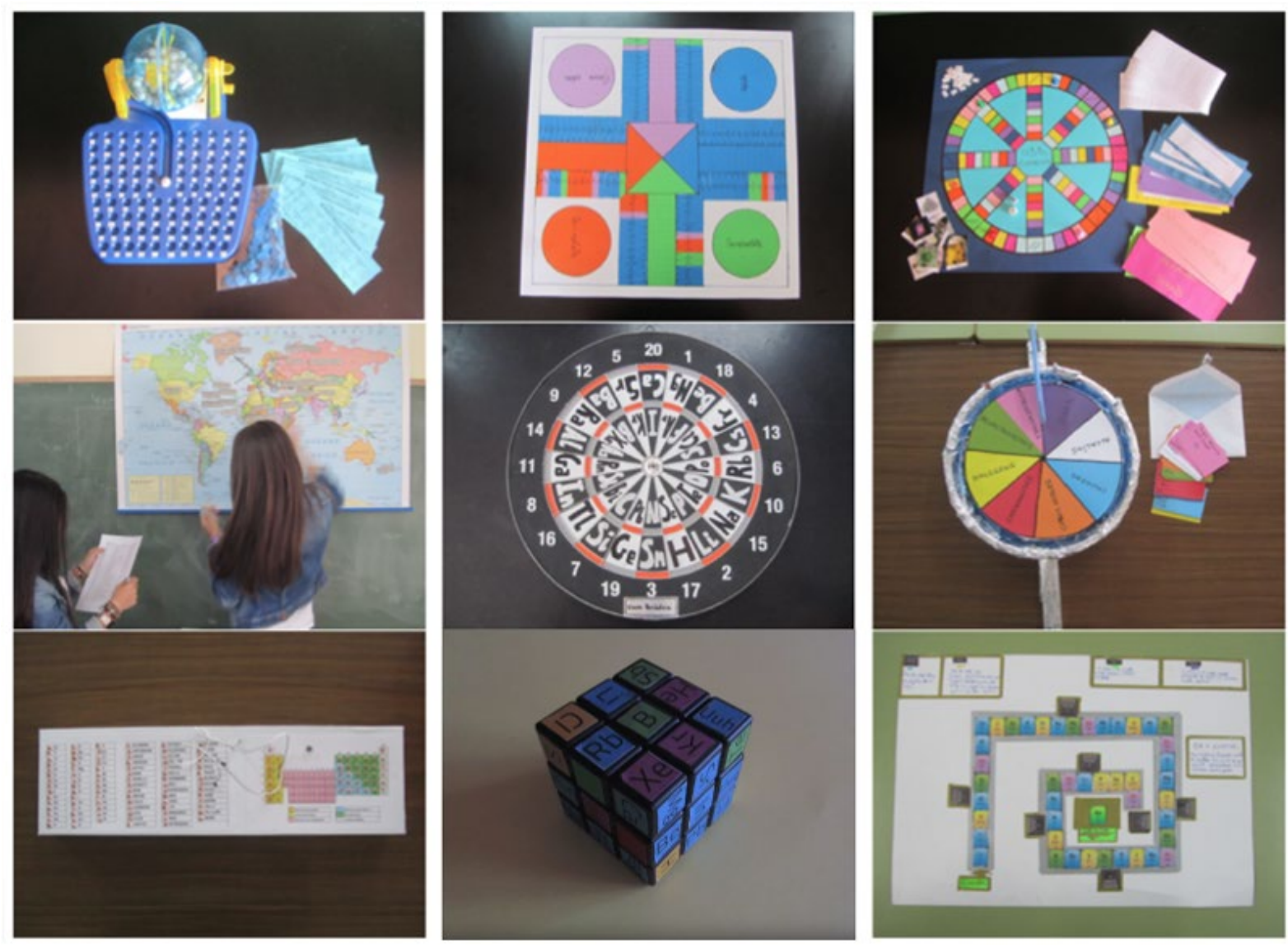

Figure 2. Different examples of projects based on the game developed by students

the periodic table. This test was carried out both in the five academic courses in which they worked by projects and with the aforementioned webquest, as well as in the three following academic courses in which the knowledge of the periodic table was worked with more traditional and rote methods. Table 2 shows the results obtained during six academic years, three of them working through the webquest and the last three using memory methods. It is found that the students who worked through the use of the game created by him as a project resulting from The webquest used obtained better results than the students who learned the periodic table by other more traditional methods.

These results of Table 2 allow us to affirm that the learning of students who worked by projects, where a majority used the game as a didactic strategy, is much more significant than that produced by the other students who did not have contact with the methodology by projects or with the game.

Numerous games elaborated as a final project about the periodic table during the five years of the investigation are shown in Figure 2. Most of the games had multiplayer modes that students created in order to enroll with their colleagues, whereas in Figure 3 different kinds of projects based on other techniques are shown (such as gastronomic projects, artistic projects, and different types of crafts). 

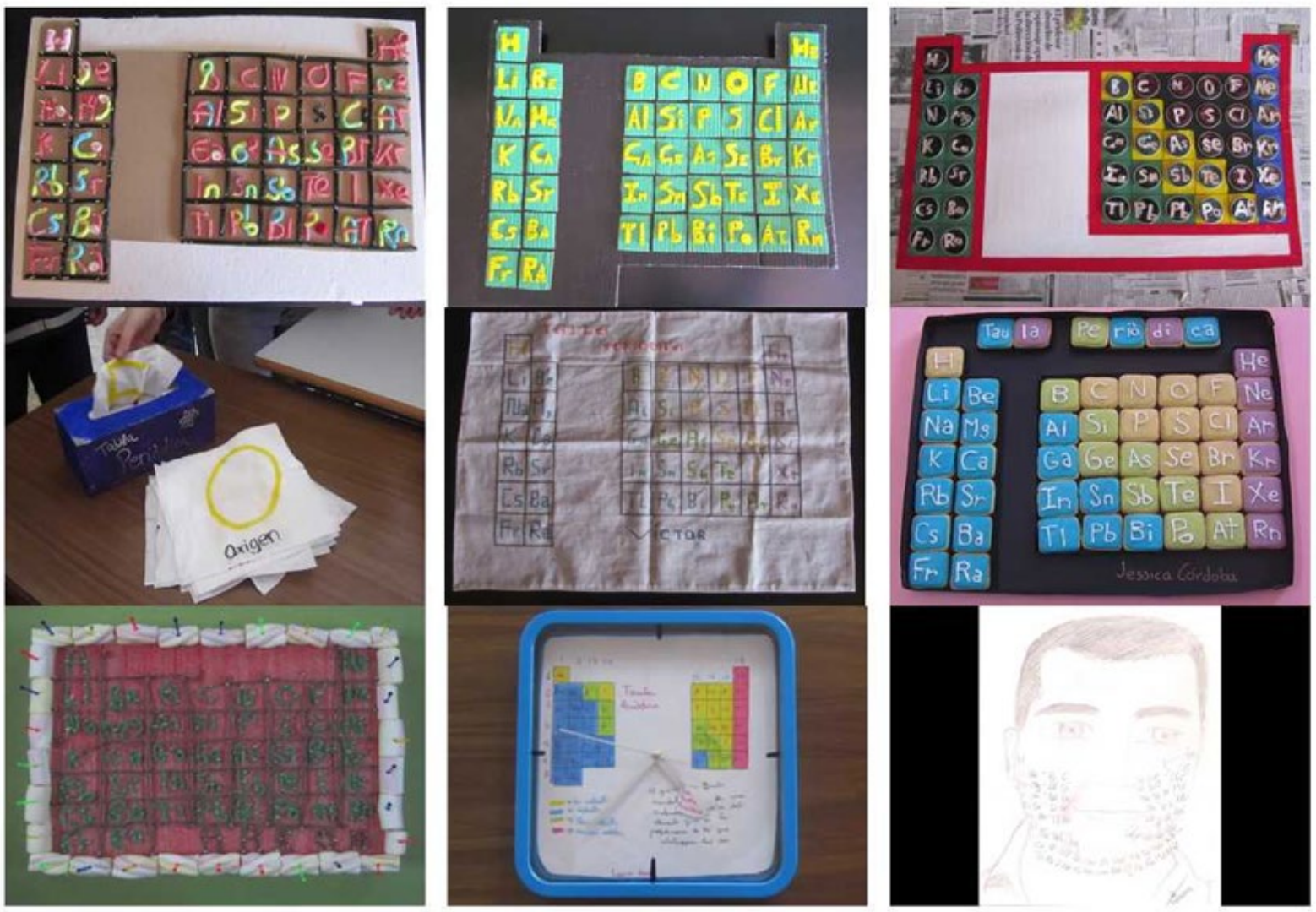

Figure 3. Different examples of projects not related to the game

From a coeducational point of view, it was also noticeable that boys submitted a cross-stitch periodic table, or girls submitted a motorcycle-related periodic table; which clearly challenged some gender related stereotypes.

\section{DISCUSSION}

The aim of this investigation was to study the relationship between learning the periodic table and the type of strategy that students choose to achieve the learning outcomes related to it. The results gathered after five years of investigation support that the students of 3rd course of secondary education opted, in the learning of science in general and the periodic table in particular, for the game as a tool since it presented motivational and fun features. This preference of the game by students over other types of strategies and tools for learning chemistry is in line with other previous studies (Bayir, 2014; Montejo \& Fernández, 2021; Najdi \& El Sheikh, 2012; Wood \& Donnelly-Hermosillo, 2019).

We assumed that students selected the way that they felt more comfortable with and were far more motivated to learn since the teacher did not determine their choice. Through the WebQuest, students learnt at their own pace and following the idea that every and each person has something within their inner self, at least one field in which we are strong at, where our skills and capacities are better than the rest, which Ken Robinson named as "the element" (Robinson, 2009). And, in this sense, each student could choose their strongest ability and feel comfortable during the project. In addition, when comparing learning through WebQuest and the use of games versus learning with more traditional learning strategies and rote methods, it was found that better academic results were obtained from the students who used the WebQuests. These results coincide with the ones of the study by Zhou et al. (2012), who also affirm that the integration of WebQuest in science teaching allows students to effectively develop critical thinking. 
Analyzing the causes of the negative attitudes towards chemistry, researchers have found that the problem was the way this subject was taught. In secondary schools the main technique to teach is usually through the master class, where the teacher explains complex chemistry contents in a decontextualized way (Akram et al., 2017; Fouts \& Myers, 1992; Furió, 2005). Students feel they must memorize lots of contents which do not have any sense for them. Consequently, they feel unmotivated towards this content and towards science in general. Moreover, teachers argue that they found issues when they had to deal with this content (Ejiwale, 2013; Mudau, 2013) because the students are not motivated or interested in learning these contents; they give up studying this subject since they think that it is too difficult to pass it, as a proof of a lack of discipline and effort. A positive correlation has been shown between the chemistry marks and the interest and a positive attitude towards this subject (Montes et al., 2018). Another important aspect that could influence the attitude of the students regarding this subject is the approach of the teacher as well as their enthusiasm (Palmer, 2007). However, neither giving good marks by default nor cheering them up over and over again are not a solution; otherwise, the solution requires to apply deeper changes like the way they teach and learn science (Hofstein \& Mamlok-Naaman, 2011). Therefore, the aim of these changes is to motivate students, to increase their interest towards chemistry (Duit \& Treagust, 2003) and, possibly, to promote that more students choose scientific careers in the future.

In the present work we have applied three of the principles that promote the intrinsic motivation (Ryan \& Deci, 2000): the competence, since we present a challenge that students must achieve; their autonomy because students had freedom to decide what kind of project they preferred to develop and they had autonomy during the session, which was indeed enhanced by the WebQuest (they could move forward on their own pace); and the purpose, since students knew that they needed to learn different learning outcomes to achieve their challenge and develop their project with success.

Some authors argue that the fundamental motivation of any game is to learn, since games are effective substitutes for traditional classroom activities, regardless of the age or the course (Belanich et al., 2004; Ebner \& Holzinger, 2007). Educational approaches which use games are based on the constructivist theory of learning. This theory suggests that if students are challenged, they will slowly get involved with the knowledge which was previously considered as too difficult (Driver \& Oldham, 1986).

The fact that the most students chose the game is expected because the game is the natural way that children learn in preschool and elementary age. However, game-based approaches for secondary school students are less common. Parents usually think that it is not possible to learn by playing and that playing is for children since using games is often considered as the opposite of hard work; nevertheless, game-based learning approaches have lots of benefits in terms to motivate students in front of the learning outcomes suggested by the teacher (Franco-Mariscal et al., 2016). Despite the variety of definitions of "play" Henricks defined some important characteristics: (i) play is an experience; (ii) it has intrinsic rather than extrinsic motivation; (iii) the process is more important that the outcome; (iv) it involves some level of active engagement (Henricks, 1999). Moreover, several researchers have found games turn into interesting tools so as to develop abstract thinking, to build mental structures, to promote spontaneous learning and to improve some abilities related to attention, memory, creativity and imagination. Moreover, they can even help students deal with issues from differents points of view (Franco-Mariscal et al., 2015; Piaget, 1978; Piaget \& Inhelder, 2008; Vigotsky, 1978). Some studies revealed that students had positive perceptions through the use of educational games in order to learn the periodic table and that make the learning process more enjoyable while it stimulates their participation in classroom activities. Furthermore, educational games are considered to help students gain a better understanding of the concepts involved in it (Franco-Mariscal et al., 2015; Franco-Mariscal et al., 2016).

An aspect that deserves to be highlighted is that some of the projects presented showed some features which were traditionally linked to one gender and have been presented by students of the other gender, which educates on gender equality and provides the students with the same opportunities. For instance, 
boys submitted a cross-stitch periodic table, whereas girls submitted a motorcycle-related periodic table; so this kind of activities could be useful to eliminate the gender stereotypes and educate on equity.

It is also important to note that the students who participated in this research not only worked on the contents of the periodic table with the PBL methodology, but also with the rest of the contents of the subject of physics and chemistry throughout the academic year. The project described here using WebQuest (http://bit.ly/wqtaula) to learn the periodic table took in all cases eight one-hour sessions (one month in total).

\section{CONCLUSIONS, LIMITATIONS AND FUTURE LINES OF RESEARCH}

Our study, coinciding with others already mentioned, shows that students prefer the game to other types of resources and that positive attitudes are generated towards learning chemistry in general and the periodic table in particular. Likewise, more meaningful learning is achieved, as reflected by better academic results. This gives the result of a preference for the use of the game for the learning of the periodic table by the students, a greater value if possible and greater efficiency, because with this methodology not only the contents of the subject were worked, but also It also served to develop numerous basic competencies in students.

The game is an excellent strategy to make the learning process easier, indeed, there was an increase of interest and of the evaluation of the periodic table by the students of secondary education. When students could freely choose what kind of tool they wanted to use in order to learn the periodic table, unleashing the skills they were strong at, we observe that the vast majority (more than $70 \%$ of the students) chose to create games that could be played with other students. These types of activities using active methodologies to learn the periodic table have shown that students, in general, prefer to learn through the game.

Nowadays, it cannot be overlooked the fact that students can have access to the information of the periodic table on their tips thanks to ICT, so it is not necessary that students should memorize all the chemical elements' features. The use of different types of strategies, far from those techniques based on repetition and memorizing, seems to be more effective to motivate and to increase the interest towards this content. The conclusion of this work is that the game is the methodology chosen by the 3rd year students of secondary education for 5 consecutive years in order to develop their project related to the periodic table. This shows that despite being teenagers this way of learning is still their favorite among many high school students and, as some authors say, playing is a natural way through which we learn, regardless of the age.

We recognize that this research has some limitations. Mainly, not all the possible variables and factors that could affect the results have been considered. Such as, for example, the previous preparation of the students in previous stages, the attitude of the teachers towards the subject, the time dedicated to carrying out the project, etc.). After 5 academic years, in which the results are consistent, we can affirm that the students of the 3rd year of secondary education choose the game as a strategy to learn the names and symbols of the elements of the periodic table. In addition, it is observed that the learning that occurs through this practice provides better results compared to other types of more traditional practices and strategies. Likewise, our research opens the way to future lines of research in which aspects such as, check if the same results are obtained with students from later stages; compare the results with students from other schools and with other teachers who work in the same way; compare two groups of students, one of control applying more traditional teaching and the other experimental with game-based teaching, and observe if there are differences in learning.

Author contributions: All authors were involved in concept, design, collection of data, interpretation, writing, and critically revising the article. All authors approve final version of the article.

Funding: The authors received no financial support for the research and/or authorship of this article.

Declaration of interest: Authors declare no competing interest.

Data availability: Data generated or analysed during this study are available from the authors on request. 


\section{REFERENCES}

Abdullahi, H. (2014). The role of ICT in teaching science education in schools. International Letters of Social and Humanities Sciences, 19, 217-223. https://doi.org/10.18052/www.scipress.com/ILSHS.19.217

Ainley, M., \& Ainley, J. (2011a). Student engagement with science in early adolescence: The contribution of enjoyment to students' continuing interest in learning about science. Contemporary Educational Psychology, 36(1), 4-12. https://doi.org/10.1016/j.cedpsych.2010.08.001

Ainley, M., \& Ainley, J. (2011b). Cultural Perspective on the Structure of Student Interest in Science. International Journal of Science Education, 33(1), 51-71. https://doi.org/10.1080/09500693.2010.518640

Akram, T. M., Ijaz, A., \& Ikram, H. (2017). Exploring the Factors Responsible for Declining Students' Interest in Chemistry. International Journal of Information and Education Technology, 7(2), 88. https://doi.org/10.18178/ijiet.2017.7.2.847

Alberts, B. (2009). Restoring science to science education. Issues in Science and Technology, 25(4), 77-80.

Álvarez-Herrero, J.F. (2019). Las webquest como soporte y mejora del Aprendizaje Basado en Proyectos en las áreas de ciencias de educación secundaria [The webquests as support and improvement of Project Based Learning in the areas of science of secondary education]. In REDINE (ed.), Conference Proceedings EDUNOVATIC 2018 (pp. 148-151). Adaya Press.

Bayir, E. (2014). Developing and playing chemistry games to learn about elements, compounds, and the periodic table: Elemental Periodica, Compoundica, and Groupica. Journal of Chemical Education, 91(4), 531-535. https://doi.org/10.1021/ed4002249

Beehr, T. A., Ivanitskaya, L., Hansen, C. P., Erofeev, D., \& Gudanowski, D. M. (2001). Evaluation of 360-degree feedback ratings: Relationships with each other and with performance and selection predictors. The International Journal of Industrial, Occupational and Organizational Psychology and Behavior, 22(7), 775-788. https://doi.org/10.1002/job.113

Belanich, J., Sibley, D. E., \& Orvis, K. L. (2004). Instructional characteristics and motivational features of a PC-based game (No. ARI research report -1822). Army Research Institute for the Behavioral and Social Science. https://doi.org/10.21236/ADA422808

Demircioğlu, H., Demircioğlu, G., \& Çalik, M. (2009). Investigating the effectiveness of storylines embedded within a contextbased approach: the case for the Periodic Table. Chemistry Education Research and Practice, 10(3), 241-249. https://doi.org/10.1039/B914505M

Dodge, B. (1998). WebQuests: a strategy for scaffolding higher level learning. National Educational Computing Conference, San Diego, 22-24 June 1998.

Driver, R., \& Oldham, V. (1986). A constructivist approach to curriculum development in science. Studies in Science Education, 13, 105-122. https://doi.org/10.1080/03057268608559933

Duit, R., \& Treagust, D. F. (2003). Conceptual change: A powerful framework for improving science teaching and learning. International journal of science education, 25(6), 671-688. https://doi.org/10.1080/09500690305016

Ebner, M., \& Holzinger, A. (2007). Successful implementation of user-centered game based learning in higher education: An example from civil engineering. Computers $\mathcal{E}$ education, 49(3), 873-890. https://doi.org/10.1016/j.compedu.2005.11.026

Ejiwale, J. (2013). Barriers to successful implementation of STEM education. Journal of Education and Learning, 7(2), 63-74. https://doi.org/10.11591/edulearn.v7i2.220

Fouts, J. T., \& Myers, R. E. (1992). Classroom environments and middle school students' views of science. The Journal of Educational Research, 85(6), 356-361. https://doi.org/10.1080/00220671.1992.9941138

Franco-Mariscal, A. J., \& Oliva-Martínez, J. M. (2012). Dificultades de comprensión de nociones relativas a la clasificación periódica de los elementos químicos: la opinión de profesores e investigadores en educación química [Difficulties in understanding notions related to the periodic classification of chemical elements: the opinion of teachers and researchers in chemistry education]. Revista científica, 2(16), 53-71. https://doi.org/10.14483/23448350.4023

Franco-Mariscal, A. J., Oliva-Martínez, J. M., \& Almoraima Gil, M. L. (2015). Students' perceptions about the use of educational games as a tool for teaching the periodic table of elements at the high school level. Journal of Chemical Education, 92(2), 278285. https://doi.org/10.1021/ed4003578

Franco-Mariscal, A. J., Oliva-Martínez, J. M., Blanco-López, Á., \& Espana-Ramos, E. (2016). A game-based approach to learning the idea of chemical elements and their periodic classification. Journal of Chemical Education, 93(7), 1173-1190. https://doi.org/10.1021/acs.jchemed.5b00846

Freeman, S., Eddy, S. L., McDonough, M., Smith, M. K., Okoroafor, N., Jordt, H., \& Wenderoth, M. P. (2014). Active learning increases student performance in science, engineering, and mathematics. Proceedings of the National Academy of Sciences, 111(23), 8410-8415. https://doi.org/10.1073/pnas.1319030111

Furió, C. J. (2005). La motivación de los estudiantes y la enseñanza de la Química. Una cuestión controvertida [The motivation of the students and the teaching of Chemistry. A controversial issue]. Educación química, 17(4e), 222-227. https://doi.org/10.22201/fq.18708404e.2006.4e.66011

Gauchat, G., \& Andrews, K. T. (2018). The cultural-cognitive mapping of scientific professions. American Sociological Review, 83(3), 567-595. https://doi.org/10.1177/0003122418773353

Gibson, H. L., \& Chase, C. (2002). Longitudinal impact of an inquiry-based science program on middle school students' attitudes toward science. Science education, 86(5), 693-705. https://doi.org/10.1002/sce.10039 
González-Gómez, D., Jeong, J. S., \& Rodríguez, D. A. (2016). Performance and perception in the flipped learning model: an initial approach to evaluate the effectiveness of a new teaching methodology in a general science classroom. Journal of Science Education and Technology, 25(3), 450-459. https://doi.org/10.1007/s10956-016-9605-9

Henricks, T. S. (1999). Play as ascending meaning: Implications of a general model of play. In S. Reifel (ed.) Play \& Culture Studies, (Vol. 2, pp. 257-278). Ablex Publishing Corporation.

Hofstein, A., \& Mamlok-Naaman, R. (2011). High-school students' attitudes toward and interest in learning chemistry. Educación química, 22(2), 90-102. https://doi.org/10.1016/S0187-893X(18)30121-6

Ibáñez-González, M. J., \& Mazzuca-Sobczuk, T. (2018). Active Methodologies in Chemistry. Proceedings, 2(21), 1339, 1-6. https://doi.org/10.3390/proceedings2211339

Joag, S. D. (2014). An Effective Method of Introducing the Periodic Table as a Crossword Puzzle at the High School Level. Journal of Chemical Education, 91(6), 864-867. https://doi.org/10.1021/ed400091w

Kangas, M., Koskinen, A., \& Krokfors, L. (2017). A qualitative literature review of educational games in the classroom: the teacher's pedagogical activities. Teachers and Teaching, 23(4), 451-470. https://doi.org/10.1080/13540602.2016.1206523

Longino, H. E. (1990). Science as social knowledge: Values and objectivity in scientific inquiry (pp. 3-15). Princeton University Press. https://doi.org/10.1515/9780691209753

Martí-Centelles, V., \& Rubio-Magnieto, J. (2014). ChemMend: A card game to introduce and explore the periodic table while engaging students' interest. Journal of Chemical Education, 91(6), 868-871. https://doi.org/10.1021/ed300733w

Méndez, D. (2015). Estudio de las motivaciones de los estudiantes de secundaria de física y química y la influencia de las metodologías de enseñanza en su interés [Study of the motivations of secondary students of physics and chemistry and the influence of the methodologies of education in their interest]. Educación XX1, 18(2), 215-235. https://doi.org/10.5944/educXX1.14016

Montejo Bernardo, J. M., \& Fernández González, A. (2021). Chemical Battleship: Discovering and Learning the Periodic Table Playing a Didactic and Strategic Board Game. Journal of Chemical Education, 98(3), 907-914. https://doi.org/10.1021/acs.jchemed.0c00553

Montes, L. H., Ferreira, R. A., \& Rodríguez, C. (2018). Explaining secondary school students' attitudes towards chemistry in Chile. Chemistry Education Research and Practice, 19(2), 533-542. https://doi.org/10.1039/C8RP00003D

Mudau, A. V. (2013). Teaching Difficulties from Interactions and Discourse in a Science Classroom. Journal of Educational and Social Research, 3(3), 113-120. https://doi.org/10.5901/jesr.2013.v4n3p113

Najdi, S., \& El Sheikh, R. (2012). Educational games: do they make a difference?. Procedia-Social and Behavioral Sciences, 47, 48-51. https://doi.org/10.1016/j.sbspro.2012.06.612

Ogembo, J. O., Otanga, H., \& Yaki, R. N. (2015). Students' and Teachers' Attitude and Performance in Chemistry in Secondary Schools in Kwale County, Kenya. Global Journal of Interdisciplinary Social Science, 4(3), 39-43.

Olakanmi, E. E. (2017). The effects of a flipped classroom model of instruction on students' performance and attitudes towards chemistry. Journal of Science Education and Technology, 26(1), 127-137. https://doi.org/10.1007/s10956-016-9657-x

Oon, P. T., \& Subramaniam, R. (2011). On the declining interest in physics among students - from the perspective of teachers. International journal of Science education, 33(5), 727-746. https://doi.org/10.1080/09500693.2010.500338

Orlik, Y. (2002). Modern organization of classes and extraclass work in Chemistry. In Chemistry: Active Methods of Teaching and Learning, chapter 10. Iberoamerica Publicaciones.

Osborne, J., \& Dillon J. (2008). Science education in Europe: Critical reflections (Vol. 13). The Nuffield Foundation.

Palmer, D. (2007). What is the best way to motivate students in science? Teaching Science: The Journal of the Australian Science Teachers Association, 53(1), 38-42.

Piaget, J. (1978). La formation du symbole chez l'enfant: imitation, jeu et rêve, image et representation [Symbol formation in children: imitation, play and dream, image and representation]. FeniXX.

Piaget, J., \& Inhelder, B. (2008). The psychology of the child. Basic books.

Prieto, T., España, E., \& Martín, C. (2012). Algunas cuestiones relevantes en la enseñanza de las ciencias desde una perspectiva Ciencia-Tecnología-Sociedad [Some relevant issues in science teaching from a Science-Technology-Society perspective]. Revista Eureka sobre Enseñanza y Divulgación de las Ciencias, 9(1), 71-77. https://doi.org/10.25267/Rev_Eureka_ensen_divulg_cienc.2012.v9.i1.05

Rastegarpour, H., \& Marashi, P. (2012). The effect of card games and computer games on learning of chemistry concepts. ProcediaSocial and Behavioral Sciences, 31, 597-601. https://doi.org/10.1016/j.sbspro.2011.12.111

Robinson, K. (2009). The element: How finding your passion changes everything. Viking.

Ryan, R., \& Deci, E. (2000). Self-determination theory and the facilitation of intrinsic motivation, social development, and wellbeing. American Psychologist, 55(1), 68.

Salta, K., \& Tzougraki, C. (2004). Attitudes toward chemistry among 11th grade students in high schools in Greece. Science Education, 88, 535-547. https://doi.org/10.1002/sce.10134 
Sutherland, R., Armstrong, V., Barnes, S., Brawn, R., Breeze, N., Gall, M., Matthewman, F. O., Taylor, A., Triggs, P., Wishart, J., \& John, P. (2004). Transforming teaching and learning: embedding ICT into everyday classroom practices. Journal of Computer Assisted Learning, 20(6), 413-425. https://doi.org/10.1111/j.1365-2729.2004.00104.x

Tai, R. H., Liu, C. Q., Maltese, A. V., \& Fan, X. (2006). Planning early for careers in science. Science, 312(5777), 1143-1144. https://doi.org/10.1126/science.1128690

Tarhan, L., \& Acar-Sesen, B. (2013). Problem based learning in acids and bases: Learning achievements and students' beliefs, Journal of Baltic Science Education, 12(5), 565-578. https://journals.indexcopernicus.com/search/article?icid=1075977

Valenti, S. S., Masnick, A. M., Cox, B. D., \& Osman, C. J. (2016). Adolescents' and Emerging Adults' Implicit Attitudes about STEM Careers: "Science Is Not Creative". Science Education International, 27(1), 40-58. https://eric.ed.gov/?id=EJ1100157

Vesterinen, V. M., Tolppanen, S., \& Aksela, M. (2016). Toward citizenship science education: what students do to make the world a better place? International Journal of Science Education, 38(1), 30-50. https://doi.org/10.1080/09500693.2015.1125035

Vygotsky, L. S. (1978). The role of play in development. Mind in society, 5, 92-104.

Webb, M. E. (2005). Affordances of ICT in science learning: implications for an integrated pedagogy. International journal of science education, 27(6), 705-735. https://doi.org/10.1080/09500690500038520

Wilkerson, D. J., Manatt, R. P., Rogers, M. A., \& Maughan, R. (2000). Validation of student, principal, and self-ratings in 360 feedback ${ }^{\circledR}$ for teacher evaluation. Journal of Personnel Evaluation in Education, 14(2), 179-192. https://doi.org/10.1023/A:1008158904681

Wilson, S. B. \& Varma-Nelson, P. (2016). Small Groups, Significant Impact: A Review of Peer-Led Team Learning Research with Implications for STEM Education Researchers and Faculty. Journal of Chemical Education, 93(10), 1686-1702. https://doi.org/10.1021/acs.jchemed.5b00862

Wood, J., \& Donnelly-Hermosillo, D. F. (2019). Learning chemistry nomenclature: Comparing the use of an electronic game versus a study guide approach. Computers $\mathcal{E}$ Education, 141, 103615. https://doi.org/10.1016/j.compedu.2019.103615

Zapata, J. (2016). Contexto en la enseñanza de las ciencias: análisis al contexto en la enseñanza de la física [Context in the teaching of science: analysis of the context in the teaching of physics]. Góndola, enseñanza y aprendizaje de las ciencias, 11, 193-211. https://doi.org/10.14483/udistrital.jour.gdla.2016.v11n2.a3

Zhou, Q., Ma, L., Huang, N., Liang, Q., Yue, H., \& Peng, T. (2012). Integrating webquest into chemistry classroom teaching to promote students' critical thinking. Creative Education, 3(03), 369. https://doi.org/10.4236/ce.2012.33058 